\title{
Ergonomics analyses of five joineries located in Florianópolis-SC, using the LEST Method
}

\author{
Lizandra Lupi Garcia Vergara ${ }^{\mathrm{a},},{ }^{*}$, Carolina Schwinden Garcia ${ }^{\mathrm{a}}$, Felipe Vergara Miranda ${ }^{\mathrm{a}}$ \\ ${ }^{a}$ Production and Systems Department, Universidade Federal de Santa Catarina, Campus Universitário Reitor \\ João David Ferreira Lima Trindade, CEP: 88040-970, Florianópolis, SC, Brazil
}

\begin{abstract}
Considering the goal of Ergonomic Work Analysis to establish, from the point of view of workers, safe, healthy, comfortable and efficient environments, this study propose to analyze the work situation of machine operators at five joineries from Florianópolis-SC. For this, it was applied the LEST Method to evaluate the task made by the operators, considering the physical, cognitive and organizational work environment. As results, it was identified the main ergonomics problems of these workstations, presenting an ergonomic diagnosis and their implications on health and safety of workers. As result, it was concluded that the main ergonomics problems at joineries are related with noise, with constant load of weight and with the postures taken. Besides these problems, others were diagnosed, for example, the pressure for workers to comply strictly the task stipulated and also the poor training and capacity of workers.
\end{abstract}

Keywords: Ergonomics, joineries, LEST method

\section{Introduction}

Joineries use tools and machines to turn wood in furnishings or objects with varied utilities to their consumers. They are inside a market that has an excess of competition, a high labour demand and few previous training, what increases considerably the risks to worker's health. Problems ranging from risks of accidents to risks of allergy, inhalation of dust and sawdust, risks of small accidents with barbs, to problems related with constant exposition to noise, weight carries, maintenance of inadequate postures, throw others harmfulness.

This study aims to analyse ergonomics problems that can affect the labour activity of machines operators, considering as sample workers from five joineries located at Florianópolis, Santa Catarina.

\section{Methodology}

To identify and analyse the ergonomics problems, it was used as support tool to ergonomics evaluation of work, the LEST method (Laboratoire d'Economie et Sociologie du Tra-vail). For this purpose visits to the selected joineries were made and data was collected. The collection of data was made both objectively, by noise measurement, temperature and luminosity as subjectively, by interview with workers and observations in the workplace, it was also made measurements to evaluate postures, efforts, movements and transports.

The equipments used for measurements were: sound pressure level meter (Cat. No. 33-2055) brand Radio Shack, psychrometer brand Instrutherm and light meter brand Ininipa.

\subsection{The LEST method}

The method used in this paper was the LEST method - method developed by the laboratory members F. Guélaud, M.N. Beauchesne e J. Gau-trat y G. Roustang, in 1978 (DASÍ et al, 2004).

For the diagnosis it is considered fourteen variables grouped into six aspects. In Table 1 the variables are grouped into its respective aspect:

\footnotetext{
${ }^{*}$ Corresponding author. E-mail: editorial@iospress.nl. Check if the checkbox in menu Tools/Options/Compatibility/Lay out footnotes like Word 6.x/95/97 is selected if you make a footnote for the corresponding author.
} 
Table 1

Division of the aspects and its respective variables according to LEST method.

\begin{tabular}{|l|l|l|l|l|l|}
\hline Physical Load & Physical Environment & Mental Load & Psychosocial Aspects & Social Status & Working Time \\
\hline Static Load & Thermal Environment & Time Pressure & Initiative & Social Status & Working Time \\
\hline Dynamic Load & Noise & Attention & Communication & \\
\cline { 2 - 4 } & Illumination & Complexity & Relationship with command \\
\cline { 2 - 5 } & Vibrations & \multicolumn{2}{|l}{} \\
\cline { 2 - 5 } &
\end{tabular}

The objective of the method is to evaluate the work conditions, classified as: satisfactory, uncomfortable and noxious, based on Table 2, pointing to factors that can have influence on the health and on the personal life of workers.

Table 2

Punctuation used by LEST method to evaluate the ergonomics risks.

\begin{tabular}{|l|l|}
\hline $0,1,2$ & Satisfactory situation \\
\hline $3,4,5$ & Light diseases - Some improvements are necessary \\
\hline 6,7 & Mean diseases - There is risk of fatigue \\
\hline 8,9 & Strong diseases - Fatigue \\
\hline 10 & Noxiousness \\
\hline
\end{tabular}

\subsection{Evaluated aspects by LEST method}

- It was considered as Physical Aspects: physical load and physical environment, with its respective variables. To the measurements of these aspects it was observed postures, weight carried, distances and temperature, noise and vibrations measurements, considering the time that workers are exposed to these conditions.

- It was considered as Cognitive Aspects: the mental load and its variables. Questions related with the time of task learning, pauses and its interferences on the chain work, level and duration of the attention, the complexity, the possibility to happen work accidents, among others were considered to measure this aspect.

- It was considered as Organizational Aspects: the psychosocial aspect, the social status and the working time, with its respective variables. The collected data were related with the possibility of modify the order of productive aspects, make mistakes, communication, the influence of the worker on product quality, hierarchical control, the frequency that the worker receive instructions, required training, working hours, hours overtime, rests and breaks, tolerance to delays, among others.

\section{Results}

The survey results referred to the five joineries evaluated were analysed considering the obtained means to the three ergonomic aspects, as follows: 8.4 to physical ones, 3.6 to cognitive ones and 4.2 to organizational ones, what can be verified at the graphic representation.

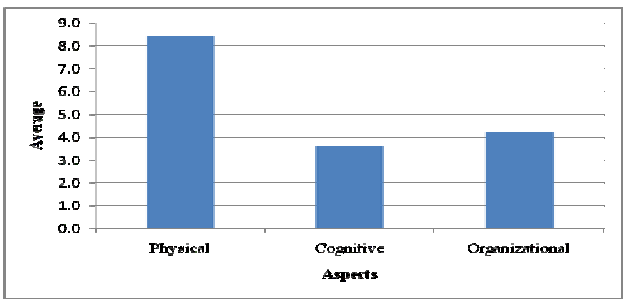

Figure 2 - Ergonomic aspects average 


\subsection{Evaluation of physical, cognitive and organizational aspects}

In the evaluation results of joineries, the physical load pointed to fatigue risks, with a mean punctuation 6.9. This aspect considers postures, weights and walked distances. The variable static load, averaging 8.2 , shows existence of fatigue. The main cause for this diagnosis is related with postures taken by workers and because they stay a long time working on standing position. For the dynamic load, averaging 5.2 , some improvements are necessary.

With an average 9.8 caused by noise of varied sources during all the workday, the physical environment was evaluated as harmful.

A problem was also diagnosed in the joineries luminosity. According to Iida (2005), the illumination level to medium hand work and general workshop must be between 400 and 600 lux. Thus, all the measured work stations pointed to an insufficient level of illumination, except one joinery, that presented a sufficient general level of illumination.

The mental load evaluation presented a mean of 3.6 what point to necessity of some improvements related to the cognitive aspects. There are not, however, an overload in the activity made by workers. But the "pressure time" variable presented a mean 4,6 that can be related with the chain work and with the necessity of recover delays.

In relation to the psychosocial aspect, that showed a mean 4.2, some improvements are necessary. Besides this, the variables 'initiative' and 'communication' emphasize that workers have a lot of autonomy. However, noise makes impossible the communication between workers. The variable "relationship with command" pointed to fatigue risks, showed by the mean 6.8. The main cause for this diagnosis is related with the fact that although workers have enough autonomy in their work, they must follow the requirements of tasks to be done with quality and established deadline by the enterprise, what demands great responsibity.

The 4.4 mean to social status aspect, pointed to the fact that a necessity of improvements is required at the work environment. It can be observed that while two joineries obtained a punctuation zero - a satisfactory situation, another two scored 8.0 and 9.0, what shows serious problems, mainly related with worker formation and with previous experience required by the enterprise.

With a mean 4.1, the working time indicates the necessity of some improvements, but the evaluation demonstrate that, in general, the organization of work is well divided over the shifts and established breaks, there are not an excess of work load. Just one joinery pointed to the risk of fatigue, because of the punctuation 6.0 in this aspect.

\section{Conclusions}

The evaluation made in this research, shows concordance because joineries are environments that workers are mainly exposed to noise, to constant carries of weight and to a wear caused by postures taken and because the fact that the labour is made standing, with static posture, during all the work day. So, the most serious problems are related with the physical environment and physical load aspects. Another problem is the fact that workers surfer a pression on the performance of the task, because they have to follow strictly the stipulated tasks. It was also noted that in two evaluated joineries there are problems related with the poor training of workers.

This research emphasize the necessity of immediate improvements at work environment of joineries to provide adequate conditions to work and less harmful conditions to health and life of workers - in this case machine operators.

\section{References}

[1] IIDA, Itiro. ERGONOMIA: Projeto e Produção. Edgard Blücher. São Paulo, 2005.

[2] GONTIJO, L. A. et al. A articulação entre o trabalho prescrito versus trabalho real: Análise da atividade de uma operadora em uma UAN. Em: XVIII Simpósio de Engenharia de Produção, SIMPEP-2000, Bauru, SP, Brasil, 2010.

[3] DASÍ, M. C.; MÁS, J. A. D.; MARZAL, J. A. Laboratorio de Ergonomía. Alfaomega Grupo Editor. México, 2004.

[4] SILVA, K. R. et al. Avaliação do Perfil de Trabalhadores e das Condições de Trabalho em Marcenarias no Município de Viçosa - MG. Revista Árvore, vol. 26, no 6, Viçosa, Nov./Dez. 2002.

[5] VIDAL, M. C. Introdução à Ergonomia. Disponível em: http://maxipas1.tempsite.ws/principal/pub/anexos/200808080 53544introducaoergonomia.pdf. Acesso em junho de 2011.1991 . 